\title{
Inbound Open Innovation in Financial Services
}

\author{
Andrey Martovoy', Anne-Laure Mention², Marko Torkkeli
}

\begin{abstract}
In the existing literature on innovation, financial services firms are attributed with a dependence on external knowledge inputs. Meanwhile, relative importance of sources of knowledge for innovation, modes of knowledge inflow, cooperation partners, advantages and disadvantages of cooperation for innovation remain underexplored. This study has unveiled that the most important internal sources of knowledge for innovation in financial services are frontline employees, new service development teams, bank executives, and backstage staff. Highly valuable modes of knowledge inflow for innovation are human resource development, purchase of equipment, and informal personal interactions. Financial services firms benefit from cooperation for innovation with external partners in the following aspects: increase in customer satisfaction, developed new skills of employees, new technologies, access to knowledge and expertise, decreased costs, and finding a new approach to solve a problem. Costs associated with external cooperation for innovation remain the most influential disadvantage of this mode of inbound open innovation.
\end{abstract}

Keywords: inbound open innovation; financial innovation; new service development; advantages and disadvantages; benefits and costs; financial services; banking services; inter-firm cooperation

I,2 IT for Innovative Services (ITIS), Luxembourg Institute of Science and Technology (LIST), 29 Avenue John F Kennedy, Luxembourg, Luxembourg, L-1855, +352 275888 - I, E-mail: andrey.martovoy@list.lu (corresponding author).

${ }^{3}$ Lappeenranta University of Technology, Skinnarilankatu 34, Lappeenranta; Finland. 


\section{Introduction}

In the existing literature on innovation, financial services firms have been traditionally attributed with a dependence on external technologies and other types of knowledge (e.g., Barras, 1986; 1990). Data from Community Innovation Survey (CIS, 2008) demonstrate that financial institutions resort to various sources of information to develop new or improve existing services: members of firm's group, professional and industry associations, suppliers, clients, competitors, and etc. However, not all sources and modes of knowledge inflow available to an innovating firm have been addressed in existing studies. Relative importance of the flows of incoming knowledge for innovation in financial services remains underexplored. Furthermore, existing studies do not give a comprehensive explanation of why most financial services firms remain "ivory towers" in their innovation activity while others resort to cooperation with external partners. In this study, we have attempted to address these research issues from the perspective of open innovation. The chosen research avenue is one of the frontiers in the open innovation research domain (Dahlander and Gann, 20I0; Huizingh, 20II) and represents a promising topic within the stream of studies on financial innovation (Mention and Torkkeli, 20I2).

We have approached the identified research issues from the premises of inbound open innovation that refers to an internal use of knowledge available outside organisational boundaries (Chesbrough, et al., 2006; Gassmann and Enkel, 2004). References to the role of different sources of knowledge for innovation in financial services can be found in the stream of literature on new service development: sequence of stages (e.g., Vermeulen, 2004; Thomke, 2003), internal sources (e.g., de Brentani and Cooper, 1992; Rossignoli and Arnaboldi, 2009; Thomke, 2003), external sources (e.g., Avlonitis, et al., 200I; Menor and Roth, 2008; Vermeulen, 2004), modes of knowledge inflow (Cooper, et al., 1994; Costanzo and Ashton 2006; de Brentani and Cooper, 1992), and advantages and disadvantages of the inbound open innovation (e.g., Dahlander and Gann, 2010; Huizingh, 20I I). Meanwhile, specific aspects of inbound open innovation in financial services require further research attention. These areas have been identified and further formulated as respective research questions addressed in this study: What are the most important partners and internal / external sources of knowledge for innovation in financial services? What are the most important modes of knowledge inflow for innovation in financial services? What are the most impactful advantages and disadvantages of cooperation for innovation in financial services?
This paper includes the following sections: literature review, research context and methods, findings and discussion, and conclusions containing managerial implications, limitations and avenues for future research.

\section{Literature review}

In this section, we review literature on innovation in financial services, introduce the concept of open innovation, discuss inbound innovation in financial services, and provide an overview of advantages and disadvantages of inbound open innovation.

\section{Innovation in financial services}

Over the last few decades, several aspects of innovation in financial services were addressed in academic literature: definition and attributes of financial innovation (Frame and White, 2004; Lerner and Tufano, 20II; Merton, 1992); its external and internal factors (de Young, et al., 2007; Furst, et al., 2002; Lerner, 2006; Silber, 1975; Yildirim and Philippatos, 2007); effects of innovation (Den Haan and Sterk, 2010; Lerner and Tufano, 20II), and financial innovation process (Anderloni and Bongini, 2009; Carvalho Veira, 2004; Lievens and Moenaert, 2000). The latter aspect was mainly addressed in the stream of publications on new service development (e.g., Cooper and de Brentani, 199I; Cooper, et al., 1994; Edgett and Jones, 1991).

Recently, scholars introduced a conceptual delineation between open and closed approaches to the innovation process. This contention is developed and empirically supported in the domain of studies on open innovation (Chesbrough, 2003; 20II) that after its emergence remains one of the most cited by both scholars and practitioners.

\section{Inbound innovation in financial services}

Chesbrough, et al. (2006) define open innovation as "the use of purposive inflows and outflows of knowledge to accelerate internal innovation, and to expand the markets for external use of innovation, respectively" (p. I). Hence, the following two approaches can be derived from this definition: the first one is the internal use of knowledge available outside organisational boundaries (inbound open innovation), while the second one stands for external exploitation of knowledge developed internally (outbound open innovation). Simultaneous usage of both approaches is referred to the coupled innovation process (Gassmann and Enkel, 2004). 
Open innovation in financial services has been conceptually and empirically tackled in several publications (e.g., Fasnacht, 2009; Mention and Torkkeli, 20I2; Oliveira and von Hippel, 20II). Importance of external knowledge inflow for financial innovation can be traced in earlier studies on new service development (NSD) (Edgett and Jones, 1991; Cooper and Edgett, 1996;Vermeulen, 2004) and organisational behaviour (e.g., Thwaites, 1992; Thwaites and Edgett, 1991). Existing literature suggests that sources of knowledge for innovation can be internal and external.

\section{Internal sources of knowledge for innovation in financial services}

Existing studies suggest that internal sources of knowledge for innovation in financial services are represented by marketing employees, employees responsible for new service development, frontline employees, operational staff, and executives. Entities belonging to a bank's group can be considered another semi-internal source of inputs for innovation.

With a few exceptions (Thomke, 2003), scholars point out that financial services firms tend have research and development projects (Rossignoli and Arnaboldi, 2009) rather than formal R\&D departments (Anderloni and Bongini, 2009). In the case when a bank sets up a dedicated R\&D team, it usually operates on an ad hoc basis (Vermeulen, 2004).

Earlier empirical studies show that involvement of marketing employees to an innovation process is important for a success of new financial services (e.g., de Brentani and Cooper, 1992; Scheuing and Johnson, 1989). Several publications pointed out that frontline personnel (often referred to "information gatekeepers" or "organisational liaisons") and operations staff are valuable internal sources for financial innovation (Lievens and Moenaert, 2000; Scheuing and Johnson, 1989). By considering suggestions originating from employees, financial services firms can shorten internal innovation process (Drew, 1995). Involvement of staff from different departments and setting up intra-project communication may have a positive impact on a success of new financial offering (Lievens and Moenaert, 2000; Vermeulen, 2004). Meanwhile, it seems that in many instances ideas for innovation originate from marketing and product development departments with a limited participation of back office employees. Besides, it appears that insufficient support from senior managers is a barrier to a smooth innovation process (Drew, 1995). Other entities that belong to a bank's group can be considered an additional internal source of knowledge for innovation (CIS, 2008).
Nevertheless, our understanding of relative importance of internal sources of inputs for innovation in financial services remains limited. Besides, the role of other internal sources in innovation process such as shareholders was not addressed in the existing studies. In order to respond to this issue, the first research question (RQ) of this study is formulated in the following way:

RQ I: What is a degree of importance of each internal source of knowledge for innovation in financial services?

\section{External sources of knowledge for innovation in financial services}

Existing data sources (e.g., CIS 2008) refer to the following external sources of knowledge for innovation: suppliers, clients, competitors, consultants, universities/ higher educational establishments, research centres, and professional and industry associations. Several conceptual and empirical papers pointed out the importance of these sources for the success of new financial offerings; however, the role of some of them remains rather controversial.

Scholars posit that clients can provide relevant ideas and suggestions to innovating financial services firms (Drew, 1995; Menor and Roth, 2008; Oliveira and von Hippel, 20II). Meanwhile, other researchers argue that customers may have difficulties in perception of their actual needs (Avlonitis, et al., 2001 ). This can be due to complexity associated with major financial products and, as a consequence, weak customers' interest in them (Vermeulen, 2004). Findings of another empirical study show that clients of financial services firms can be a good source of valuable and original ideas. Such clients usually demand complex services, interact in high volumes, have longstanding relationships, ask for tailored services, and have a strong motivation to find solutions to their problems (Martovoy and Dos Santos, 2012).

One of the most traditional concepts in the domain of innovation in services is based upon an assumption that innovation in financial services is supplier-driven (Barras, 1986; 1990). Financial institutions are seen as adopters of information and communication technologies (ICT) developed in other sectors. Several studies highlighted the role of technology and equipment suppliers in innovation in financial services (Pennings and Harianto, 1992; Uchupalanan, 2000).

Scholars contend that financial services firms benefit also from competitors by cooperating or communicating with them to deliver enhanced value to clients. For example, in addition to proprietary services, banks may opt to distribute products developed by other financial services firms including competitors (Fasnacht, 2009; Lerner, 2006). Besides, it seems that inter-firm communication during 
new service development (NSD) process helps innovators to gain knowledge about their competitors (Lievens, et al., 1999). Findings of another research show that pace of financial innovation in a region is associated with an overall propensity to innovation by a given financial firm located in that region (Lerner, 2006). This leads to the concept of knowledge spillovers addressed in the stream of publications on innovative clusters (Audretsch and Feldman, 2004; Grossman and Helpman, 1991). The role of other sources of inputs for innovation in financial services has been addressed to a lesser extent. One study concludes that closer links with higher educational establishments have no effect on financial innovation (Lerner, 2006).

In summary, the role of some external sources of knowledge for innovation in financial services remains underexplored. Are there any other sources of knowledge for innovation in financial services and what is a degree of their importance? Hence, the second research question is as follows:

RQ 2: What is a degree of importance of each external source of knowledge for innovation in financial services?

Financial institutions may not only merely source knowledge for innovation but also cooperate with external partners formally to develop new and/or improve existing services. Such entities can be similar to the ones discussed above. Aiming at exploring the role of specific cooperation partners in financial innovation, the third research question of this study is the following:

RQ3: What is a degree of importance of each external cooperation partner for innovation in financial services?

\section{Modes of inbound open innovation in financial services}

In addition to directions of knowledge flows (inward or outward) and their respective sources, a mode of knowledge flow can be a useful concept to explore the nature of inbound open innovation in financial services.

Modes of knowledge flow are means through which knowledge is transferred. Existing literature suggests that some of them are important for innovation in financial services. As compared to other means, the role of market research is one of the most studied.Available findings suggest that a market research conducted at early stages of new service development process is crucial to a success of new financial offering (e.g., Carvalho Viera, et al. 2004; Cooper, et al., 1994; Drew, 1995; Edgett, 1994; Edgett and Jones, 199I; Edgett and Parkinson, 1994; Menor and Roth, 2008). Realistic understanding of market potential and development of relevant steps to approach a market are both correlated with a financial innovation success (Johne and Davies, 2000). However, other studies unveil that financial services firms tend to avoid an analysis of clients' needs. Besides, most banks are inclined towards introduction of innovations without preceding tests on a market (de Brentani and Cooper, 1992; Vermeulen, 2004). Costanzo and Ashton (2006) argue that financial institutions are mainly driven by the aim of imitating competitors rather than listening to clients' needs.

In overall, the role of various modes of knowledge inflow for innovation in financial services remains mixed. In order to respond to this issue, the following research question is formulated:

RQ4: What is a degree of importance of each mode of knowledge inflow for innovation in financial services?

\section{Advantages and disadvantages of inbound open innovation}

As any other innovation management approach, a decision about opening up an NSD process has its respective costs and benefits which can be pecuniary and non-pecuniary, immediate or long-term, tactical or strategic (Dahlander and Gann, 20 I0; Huizingh, 20 I I). Recently, scholars reviewed a variety of pros and cons of inbound and outbound open innovation approaches (Dahlander and Gann, 2010).

\section{Advantages of inbound open innovation}

Benefits of open innovation have been largely explored in the existing literature. Earlier studies suggest that cooperation with external partners leads to development of new financial services (e.g., Fasnacht, 2009; Oliveira and von Hippel, 20I I). Financial services firms benefit from the following outcomes of cooperation with IT suppliers (Martovoy, 20I4): cost reduction, leveraging complementarities by accessing unique resources; access to partners' networks; shorter time-tomarket; and stronger credibility and trust.

Meanwhile, our understanding of the variety of advantages of inbound open innovation, usually taking a form of interfirm cooperation, remains limited. Furthermore, little is known about an impact of advantages on innovating financial institutions. To the best of our knowledge, this study is among the first ones tackling this research issue. Hence, the fifth research question is formulated as follows:

RQ5: What are the most impactful advantages for financial services firms cooperating for innovation with external partners? 


\section{Disadvantages of inbound open innovation}

As compared to the benefits of inbound open innovation, the "dark side" of this innovation management approach attracted less attention in existing literature. Nevertheless, in a few preceding studies, scholars review a variety of negative consequences and barriers associated with the inbound open innovation (Dahlander and Gann, 20l0). In the context of financial services, Martovoy (2014) reveals that cooperation for innovation is attributed with two issues: time costs associated with cooperation and bureaucracy / conflicting rules.

To summarise, disadvantages of inbound open innovation in financial services and a degree of their impact remain among the least explored topics. To the best of our knowledge, there is no dedicated study that addressed this topic quantitatively in the extant literature. Therefore, the sixth research question of our study is the following:

RQ6: What are the most impactful disadvantages for financial services firms cooperating for innovation with external partners?

\section{Research context and methods}

The formulated research questions were addressed with the help of a dedicated survey of financial services firms. We reviewed existing approaches to data collection in the domain of innovation. This effort resulted in the development of a tailored questionnaire containing a set of multiple choice questions about several dimensions of innovation activity including internal and external sources of knowledge for innovation, cooperation partners for innovation, modes of knowledge inflow, advantages and disadvantages of cooperation with external partners. The questions were formulated in English. A pilot version of the questionnaire was tested with three financial services firms. With a help of face-to-face interviews, we collected the initial feedback on a usability of the developed data collection tool. Each interview lasted about 40 munities with some extra time allowing a respondent to share his/her thoughts about the questionnaire. Taking into account the goal of our study, we scoped a profile of potential respondents to the following positions in financial services firms: chief executive officers, chief financial officers, innovation managers, and executives responsible for business development, new product development, marketing and quality.

We opted to collect the data in the Grand Duchy of Luxembourg. According to a recent report (Z/Yen Group, 2015), this country is among the most developed poles which specialise in the provision of financial services. In 2015, Luxembourg occupied 17th rank in the World and 4th rank in the Western European list of financial services centres in terms of business environment, taxation, human capital, reputation, infrastructure and development (Z/Yen Group, 2015). The financial services sector in Luxembourg is an important pillar of the national economy accounting for $38 \%$ of GDP (LFF, 20I2). Populated with different types of financial services firms, the core of the financial services sector of Luxembourg is represented by banks that generate about 19\% of GDP (LFF, 20I2). By the start of the survey, there were 142 banks authorised to conduct their business activity in Luxembourg (CSSF, 20I2). Most of those banks ( 103 entities) were the members of "Association des Banques et Banquiers, Luxembourg" (ABBL), the professional society of banks and bankers in Luxembourg. The remaining nonmember banks were mainly represented by parent credit institutions that established their presence in the country in addition to their group members operating under the respective law of Grand-Duchy of Luxembourg governing the provision of financial services (5 April, 1993).

Thus, we decided to disseminate the tailored questionnaire among the $A B B L$ banks. We approached the $A B B L$ administration and presented the goal of our study and the method of data collection. The ABBL agreed to assist us and disseminated the questionnaire among all their members by email on 3 Ist July, 20I2. Several consecutive waves of reminders took place in the period of August - November, 20I2. In a result, we succeeded to solicit 25 replies that accounts for $24.3 \%$ of the parent population. Due to the sample size, we decided to proceed with a descriptive statistical analysis.

\section{Findings and discussion}

Analysis of data has suggested that frontline employees, dedicated NSD teams, bank executives, and backstage staff remain the most important internal sources of knowledge for innovation in banking sector (Table I). The role of frontline employees and dedicated NSD teams for innovation was highlighted in existing studies (e.g., Drew, 1995; Lievens and Moenaert, 2000; 200I; Scheuing and Johnson, 1989; Vermeulen, 2004), while importance of chief executives and other supporting staff appears to be novel for the research domain. Meanwhile, appearance of CEOs in this list is, probably, due to the profile of survey respondents who were predominately senior managers. We have not found a strong support for the major role of marketing employees in financial innovation as it was argued in preceding publications (e.g., Scheuing and Johnson, 1989). Our study has shown that shareholders have the lowest importance for innovation in financial services. 


\begin{tabular}{|l|l|l|l|}
\hline & $\begin{array}{l}\text { Degree of importance } \\
\text { (mean statistic)* }\end{array}$ & Std. Error & $\begin{array}{l}\text { Std. } \\
\text { Deviation }\end{array}$ \\
\hline High importance: & & & \\
\hline Frontline employees & 2.54 & 0.12 & 0.59 \\
\hline $\begin{array}{l}\text { Team of employees responsible for service development/improve- } \\
\text { ment }\end{array}$ & 2.44 & 0.20 & 1.00 \\
\hline CEO / Board of Directors & 2.36 & 0.17 & 0.86 \\
\hline Other backstage employees & 2.08 & 0.16 & 0.81 \\
\hline Medium importance: & & & \\
\hline Marketing / business intelligence employees & 1.76 & 0.20 & 1.01 \\
\hline Low importance: & & & \\
\hline Shareholders & 0.96 & 0.18 & 0.88 \\
\hline Other & 0.23 & 0.23 & 0.83 \\
\hline
\end{tabular}

Note: $*$ The degree of importance has been measured on a scale: 0 - not used, I - low importance, 2 - medium importance, 3 - high importance.

Table I. Internal Sources of Knowledge for Innovation in Financial Services 
Variability of responses, as measured by a standard deviation, is another aspect to take into account. In this regard, opinions of respondents on the role of frontline employees tend to converge, while the perception of importance of NSD teams and marketing/business intelligence employees appears to be rather heterogeneous. Our dataset has shown that banks which serve such types of clients as high-networth individuals (HNWI), small and medium sized firms, institutions, and large firms value their NSD teams more as compared to those banks working with retail clients. Similar trend has been identified for marketing / business intelligence employees.

Relative importance of internal sources of knowledge as compared to external ones is depicted in Table 2 . Innovating banks and other members belonging to a bank group are the most important sources of inputs for innovation in financial services. Consultants, clients, suppliers, professional associations, and competitors represent another group of entities valuable for financial innovation. Non-government organisations and commercial research laboratories appear to be the least important sources knowledge for innovation in financial services. Similar to existing studies, we have found a support for the argument that clients (Drew, 1995; Menor and Roth, 2008) and suppliers (Barras, 1986, 1990; Pennings and Harianto, 1992) are valuable for financial innovation. It has been also confirmed that universities and higher educational establishments play a marginal role in knowledge sourcing strategies of banks (Lerner, 2006). In overall, it appears that the most important deposits of knowledge for innovation in banking services reside within the narrow (bank itself) and wide (a bank group) boundaries of surveyed entities. Nevertheless, we cannot conclude that banks remain "ivory towers" in terms of openness to inputs for innovation because resorting to several external sources of knowledge is also evident. The highest degree of variability of answers is observed for professional and industry associations (Table 2). This is, probably, due to the dissemination of questionnaire that was administered through a national association of banks; hence, the respective figure should be taken with a caution. Maximum homogeneity of respondents' opinions has been obtained for internal sources (within a bank) and consultants.

\begin{tabular}{|l|l|l|l|}
\hline & $\begin{array}{l}\text { Degree of importance } \\
\text { (mean statistic) }\end{array}$ & $\begin{array}{l}\text { Std. } \\
\text { Error }\end{array}$ & $\begin{array}{l}\text { Std. } \\
\text { Deviation }\end{array}$ \\
\hline High importance: & & & \\
\hline Within a bank & 2.76 & 0.10 & 0.52 \\
\hline Other entities belonging to a bank's group & 2.33 & 0.18 & 0.87 \\
\hline Medium importance: & & & \\
\hline Consultants & 2.00 & 0.13 & 0.65 \\
\hline Clients & 1.96 & 0.19 & 0.93 \\
\hline Suppliers of equipment, materials, software & 1.92 & 0.15 & 0.76 \\
\hline Professional and industry associations & 1.92 & 0.21 & 1.04 \\
\hline Competitors or other enterprises in respective sector & 1.76 & 0.18 & 0.88 \\
\hline Government, public authorities & 1.68 & 0.18 & 0.90 \\
\hline Central Bank & 1.56 & 0.19 & 0.96 \\
\hline Low importance: & & & \\
\hline Public research institutes & 1.00 & 0.14 & 0.71 \\
\hline Universities and higher education institutes & 0.80 & 0.17 & 0.87 \\
\hline $\begin{array}{l}\text { International organisations (e.g.World Bank Group, UN,WTO, OECD, } \\
\text { and etc.) }\end{array}$ & 0.76 & 0.16 & 0.78 \\
\hline Other non-government organisations & 0.74 & 0.19 & 0.92 \\
\hline Commercial laboratories, private R\&D institutes & 0.60 & 0.15 & 0.76 \\
\hline
\end{tabular}

Note: $*$ The degree of importance has been measured on a scale: 0 - not used, I - low importance, 2 - medium importance, 3 - high importance.

Table 2. Sources of Knowledge for Innovation in Financial Services

ISSN: 07 I8-2724. (http://www.jotmi.org) 
Our dataset has shown that over the period of 2010-2012 $29.3 \%$ of all innovations in financial services were developed by surveyed financial institutions without resorting to any cooperation; $48.3 \%$ of new and/or improved banking services were developed jointly with other partners (where $27.6 \%$ - with members of bank's group; $20.7 \%$ - with other partners); while $22.4 \%$ of new market offerings were a result of adoption of innovations developed externally (I7.2\% - by bank's group members; $5.2 \%$ - by other external partners).

Taking a closer look at collaboration for innovation, we can report that entities belonging to a bank group remain the most important cooperation partners for innovation in financial services (Table 3). To some extent, these research outcomes are similar to the findings on the sources of knowledge for financial innovation (Table 2). Members of bank's group are followed by consultants, suppliers, and clients whose importance appears to be moderate. These findings are in line with earlier studies that explored innovation-related cooperation of financial services firms with consultants (Drew, 1995), clients (Cooper and Edgett, 1996; Oliveira and von Hippel, 20I I), and suppliers (Pennings and Harianto, 1992; Uchupalanan, 2000). Similar to Table 2, higher educational establishments, research institutions (public and private), and international organisations are the least important partners for innovation.

\begin{tabular}{|l|l|l|l|}
\hline & $\begin{array}{l}\text { Degree of importance } \\
\text { (mean statistic) }\end{array}$ & $\begin{array}{l}\text { Std. } \\
\text { Error }\end{array}$ & $\begin{array}{l}\text { Std. } \\
\text { Deviation }\end{array}$ \\
\hline High importance: & & & \\
\hline Entities belonging to your bank's group & 2.38 & 0.21 & 0.97 \\
\hline Medium importance: & & & \\
\hline Consultants & 1.91 & 0.21 & 0.97 \\
\hline Suppliers of equipment, materials, software & 1.77 & 0.23 & 1.07 \\
\hline Clients & 1.64 & 0.23 & 1.09 \\
\hline Professional and industry associations & 1.45 & 0.26 & 1.22 \\
\hline Government, public authorities & 1.05 & 0.25 & 1.17 \\
\hline Low importance: & & & \\
\hline Central Bank & 0.86 & 0.22 & 1.04 \\
\hline Competitors or other enterprises in your sector & 0.62 & 0.18 & 0.80 \\
\hline Other non-government organisations & 0.55 & 0.17 & 0.80 \\
\hline Universities and higher education institutes & 0.45 & 0.16 & 0.74 \\
\hline Public research institutes & 0.45 & 0.13 & 0.60 \\
\hline Commercial labs, private R\&D institutes & 0.27 & 0.10 & 0.46 \\
\hline $\begin{array}{l}\text { International organisations (e.g. World Bank Group, OECD, UN,WTO, } \\
\text { and etc.) }\end{array}$ & 0.25 & 0.10 & 0.44 \\
\hline
\end{tabular}

Note: $*$ The degree of importance has been measured on a scale: 0 - not used, I - low importance, 2 - medium importance, 3 - high importance.

Table 3. Role of External Cooperation Partners for Innovation in Financial Services 
In terms of intellectual property management, surveyed banks adopt several modalities in cooperation with external partners: contracts (e.g., non-disclosure agreements, partnership agreement, and etc.) (48.6\%); secrecy (28.6\%); intellectual property law (e.g., copyrights law, trademarks law, patent law, industrial design law, and etc.) (1 I.4\%); and none (i.e. reliance on trust) (I I.4\%).

As it was discussed earlier, banks use various modes in order to enable external knowledge flows for innovation. Our findings suggest that surveyed financial services value the following three modes of knowledge inflow: hiring new personnel, purchase of equipment, and informal personal interactions (Table 4). This means that the most important knowledge for innovation in banking services is embodied in people and technological artefacts (Barras, 1986, 1990; Pennings and Harianto, 1992). Such modes as investments in existing firms, establishment of joint ventures, mergers, and acquisition of external knowledge are among the least important for innovation. The highest degree of variability of opinions has been observed for the first three modes listed above, while the exchange of copyrights, patents, trademarks, industrial designs, and trade secrets tends to be more homogeneous in terms of standard deviation.

\begin{tabular}{|l|l|l|l|}
\hline & $\begin{array}{l}\text { Degree of importance } \\
\text { (mean statistic) }\end{array}$ & $\begin{array}{l}\text { Std. } \\
\text { Error }\end{array}$ & $\begin{array}{l}\text { Std. } \\
\text { Deviation }\end{array}$ \\
\hline High importance: & & & \\
\hline $\begin{array}{l}\text { Hiring new personnel, personnel exchange (short and long-term, intern- } \\
\text { ships), and human resources professional development }\end{array}$ & 2.29 & 0.19 & 0.91 \\
\hline Purchase of machinery, equipment, computer hardware and software & 2.20 & 0.16 & 0.82 \\
\hline Informal personal interactions & 2.12 & 0.19 & 0.97 \\
\hline Medium importance: & & & \\
\hline $\begin{array}{l}\text { Market research (surveys, case studies, focus groups, observations, experi- } \\
\text { ments, and etc.) }\end{array}$ & 1.80 & 0.18 & 0.91 \\
\hline Events (conferences, fairs, exhibitions, demonstrations, shows, meetings) & 1.72 & 0.17 & 0.84 \\
\hline $\begin{array}{l}\text { Purchase of knowledge intensive services to support innovation (consult- } \\
\text { ing, design, and etc.) }\end{array}$ & 1.52 & 0.18 & 0.92 \\
\hline Publications in professional and academic journals, magazines & 1.32 & 0.17 & 0.85 \\
\hline Mass media:TV, newspapers, radio, and etc. & 1.20 & 0.19 & 0.96 \\
\hline Low importance: & & 0.24 & 1.22 \\
\hline Investments in existing firms/acquisition & 0.80 & 0.21 & $\mathrm{I} .04$ \\
\hline Establishment of joint ventures with partners & 0.64 & 0.22 & $\mathrm{I} .08$ \\
\hline Mergers & 0.56 & 0.10 & 0.48 \\
\hline $\begin{array}{l}\text { Acquisition of external knowledge (copyrights, patents, trademarks, indus- } \\
\text { trial designs, and trade secrets) }\end{array}$ & 0.32 & & \\
\hline
\end{tabular}

Note: $*$ The degree of importance has been measured on a scale: 0 - not used, I - low importance, 2 - medium importance, 3 - high importance.

Table 4. Modes of Knowledge Inflow for Innovation in Financial Services 
Importance of cooperation with external partners can be derived analytically by calculating its aggregated mean (Table 3) that in our case is equal to I.05. It means that this mode of knowledge inflow as compared to others lies between mass media (I.20) and investments in existing firms (0.80) (Table 4).

Admitting a fact that cooperation with external partners may result in various outcomes, the following part of our paper is devoted to exploring respective advantages and disadvantages of this mode of inbound open innovation.
Table 5 illustrates that cooperation with external partners (including members of bank's group) is beneficial to innovating banks because of the following: increased customer satisfaction; developed skills of employees; access to ideas, knowledge and expertise; new technologies; decreased costs; and finding new approach to solve a problem. This entails that banks gain from both pecuniary and non-pecuniary benefits of cooperation for innovation (Dahlander and Gann, 2010).

\begin{tabular}{|c|c|c|c|}
\hline & $\begin{array}{l}\text { Degree of impact } \\
\text { (mean statistic) }\end{array}$ & $\begin{array}{l}\text { Std. } \\
\text { Error }\end{array}$ & $\begin{array}{l}\text { Std. } \\
\text { Deviation }\end{array}$ \\
\hline \multicolumn{4}{|l|}{ High impact: } \\
\hline Increased customer satisfaction & 2.45 & 0.16 & 0.74 \\
\hline Our employees learned new skills & 2.27 & 0.12 & 0.55 \\
\hline $\begin{array}{l}\text { Gained access to ideas, knowledge, expertise and technologies available at } \\
\text { our partners }\end{array}$ & 2.27 & 0.15 & 0.70 \\
\hline Developed new technologies & 2.24 & 0.21 & 0.94 \\
\hline Decreased costs & 2.18 & 0.21 & 1.01 \\
\hline Found a new approach to solve a problem & 2.05 & 0.19 & 0.90 \\
\hline \multicolumn{4}{|l|}{ Medium impact: } \\
\hline Accelerated internal innovation at our bank & 1.95 & 0.21 & 1.00 \\
\hline Improved innovation process at our bank & 1.95 & 0.18 & 0.84 \\
\hline Profitable growth & 1.95 & 0.19 & 0.90 \\
\hline Shortened time-to-market & 1.86 & 0.21 & 0.99 \\
\hline Improved margins & 1.86 & 0.22 & 1.04 \\
\hline Our bank followed current market developments and clients & 1.76 & 0.26 & 1.18 \\
\hline $\begin{array}{l}\text { In terms of organisational culture our bank became more open for the } \\
\text { co-operation (e.g. internal barriers for co-operation decreased) }\end{array}$ & 1.73 & 0.19 & 0.88 \\
\hline Reinforced credibility of our bank & 1.68 & 0.21 & 0.99 \\
\hline Expanded markets & 1.59 & 0.27 & 1.26 \\
\hline Gained access to partners' networks & 1.57 & 0.24 & 1.12 \\
\hline $\begin{array}{l}\text { Improved management by reaching higher flexibility and redistribution of } \\
\text { tasks }\end{array}$ & 1.55 & 0.17 & 0.80 \\
\hline Withstood market shocks (e.g. economic crisis, turmoil, and etc.) & 1.55 & 0.26 & 1.22 \\
\hline Increased market share & 1.36 & 0.24 & 1.14 \\
\hline $\begin{array}{l}\text { Co-operation was the way to monitor potentially disruptive technologies, } \\
\text { solutions or approaches capable to threaten our bank }\end{array}$ & 1.14 & 0.18 & 0.83 \\
\hline \multicolumn{4}{|l|}{ Low impact } \\
\hline Risk of innovation was shared with partners & 1.00 & 0.21 & 0.98 \\
\hline Controlled dependence on other firms & 0.73 & 0.16 & 0.77 \\
\hline
\end{tabular}

Note: *The degree of importance has been measured on a scale: 0 - not relevant, I - low impact, 2 - medium impact, 3 - high impact. Table 5.Advantages of Cooperation for Innovation in Financial Services 
Surveyed respondents reported only one disadvantage that, in their opinion, had a significant impact on their firmscosts related to cooperation (Table 6). This finding echoes the insights of transaction costs theory (Coase, 1937) and falls into the pecuniary group of disadvantages of open innovation (Dahlander and Gann, 2010).

\begin{tabular}{|c|c|c|c|}
\hline & $\begin{array}{l}\text { Degree of impact } \\
\text { (mean statistic)* }\end{array}$ & Std. Error & $\begin{array}{l}\text { Std. } \\
\text { Deviation }\end{array}$ \\
\hline \multicolumn{4}{|l|}{ High impact: } \\
\hline Costs related to the cooperation (money, time, and etc.) & 2.09 & 0.21 & 0.97 \\
\hline \multicolumn{4}{|l|}{ Medium impact: } \\
\hline Difficulties in balancing co-operation for innovation with daily tasks & 1.33 & 0.21 & 0.97 \\
\hline Problems in communication with partners & 1.24 & 0.18 & 0.83 \\
\hline Problems with division of contributions and outcomes of co-operation & 1.23 & 0.19 & 0.87 \\
\hline Partners did not meet expectations and deadlines & 1.19 & 0.21 & 0.98 \\
\hline $\begin{array}{l}\text { Problem with maintaining internal commitment at our bank towards } \\
\text { the co-operation over a period of time }\end{array}$ & 1.19 & 0.19 & 0.87 \\
\hline Development of dependency on our partners & 1.14 & 0.19 & 0.89 \\
\hline Secrecy concerns, protection of intellectual assets & 1.05 & 0.20 & 0.95 \\
\hline \multicolumn{4}{|l|}{ Low impact } \\
\hline $\begin{array}{l}\text { Persistent corporate culture at our bank that avoids using or buying } \\
\text { already existing knowledge because of their external origins }\end{array}$ & 1.00 & 0.18 & 0.84 \\
\hline Difficulties in choosing and combining between numerous alternatives & 0.95 & 0.16 & 0.74 \\
\hline $\begin{array}{l}\text { Organisational resistance at our bank and fear of losing control over a } \\
\text { proprietary knowledge or solution }\end{array}$ & 0.95 & 0.18 & 0.80 \\
\hline Bureaucracy and conflicting rules among partners & 0.95 & 0.19 & 0.86 \\
\hline Poor governance of co-operation with the partners & 0.95 & 0.23 & 1.07 \\
\hline $\begin{array}{l}\text { Difficulties in dealing with many sources and ideas at any given moment } \\
\text { of time }\end{array}$ & 0.90 & 0.14 & 0.62 \\
\hline "Cannibalisation" of existing services of our bank & 0.80 & 0.16 & 0.70 \\
\hline $\begin{array}{l}\text { Difficulties in maintaining large number of partnerships with different } \\
\text { actors }\end{array}$ & 0.76 & 0.15 & 0.70 \\
\hline Outsourced critical dimension of our business & 0.73 & 0.20 & 0.94 \\
\hline Slowdown of innovation potential at our bank & 0.68 & 0.17 & 0.78 \\
\hline Loss of own competence & 0.68 & 0.14 & 0.65 \\
\hline Eroded creativity at our bank & 0.64 & 0.15 & 0.73 \\
\hline Decreased communication among departments of our banks & 0.62 & 0.19 & 0.86 \\
\hline Partner went on competing with our bank & 0.59 & 0.18 & 0.85 \\
\hline
\end{tabular}

Note: $*$ The degree of importance has been measured on a scale: 0 - not relevant, I - low impact, 2 - medium impact, 3 - high impact. Table 6. Disadvantages of Cooperation for Innovation in Financial Services 


\section{Conclusions}

This study represents an attempt to explore a variety of internal and external knowledge sources, modes of knowledge inflow, cooperation partners, and advantages and disadvantages of cooperation for innovation in financial services. Drawing upon a dedicated survey of banks located in Luxembourg, we have unveiled the following.

Frontline employees, dedicated NSD teams, bank executives, and backstage staff are the most important internal sources of knowledge for innovation.

The most important deposits of knowledge for innovation reside within the narrow (bank itself) and wide (bank's group) boundaries of surveyed firms. Consultants, clients, suppliers, professional associations, and competitors possess medium importance as respective sources of knowledge for innovation.

About half of innovations in financial services were developed jointly with partners where bank's group members prevail (27.6\%) over other external partners (20.7\%). Entities belonging to a bank's group appear to be the most important cooperation partners for innovation.

During cooperation, financial services firms use the following arrangements for intellectual property protection: dedicated agreements (48.6\%); secrecy (28.6\%); intellectual property law (I I.4\%). Meanwhile, about II\% of respondents use none of them and therefore rely on trust.

The most important modes of knowledge inflow for innovation in financial services are as follows: hiring new personnel / personnel exchange and professional development, purchase of equipment, and informal personal interactions.

Our sample has shown that the most impactful advantages of inbound open innovation are new skills of employees; access to ideas, knowledge and expertise; new technologies; decreased costs; and finding a new approach to solve a problem. The most influential disadvantage of inbound open innovation in financial services refers to costs associated with cooperation.

\section{Managerial implications}

We believe that the findings of this study might be helpful, first of all, for practitioners working in the financial services sector. The outcomes of this study can provide them with an overview of current innovation strategies. Almost all respondents that participated to this survey expressed their interest in having an access to its aggregated findings. This sign reinforced our belief that we were carrying out a research results of which were awaited by the target audience.

Our findings have shown that financial services firms tend to rely on and emphasise internal and semi-internal (banks' group members) sources of knowledge. In this context, almost all types of employees are highly important for financial innovation. Meanwhile, opposite to other sectors of economic activity, the role of external sources of knowledge remains moderate. This can be explained by several reasons yet to be further explored: complexity of new financial offerings, government regulation of financial services, conservatism with regard to financial innovation, organisational culture, and etc. What concerns innovationrelated cooperation with external partners, apart from high costs associated with this mode of inbound open innovation, surveyed financial services firms reported the following issues: difficulties in balancing co-operation for innovation with daily tasks; problems in communication with partners; problems with division of contributions and outcomes of co-operation; partners not meeting expectations and deadlines; maintaining internal commitment towards cooperation; development of dependency on external partners; and secrecy concerns. Therefore, banks that succeed in development of dedicated and cost effective means aimed at overcoming these issues might have an opportunity to minimise negative impacts associated with collaboration. Meanwhile, our study has shown that cooperation with external partners is associated with positive outcomes as well where benefits are both pecuniary and non-pecuniary. Each bank should take into account all potential costs and benefits of this mode of inbound open innovation, and we hope that our study may have a chance to provide them with respective insights on this challenge.

\section{Limitations and future research}

Due to a small sample size, we were restricted in proceeding with advanced statistical tests; therefore, the results of this study are mainly descriptive. A larger sample is needed in order to explore eventual relationships between innovation strategies employed by financial services firms and respective performance indicators. 
Since data for this study were collected in Luxembourg, its findings and implications can be biased due to national context and peculiarities of banking sector in this country where, for instance, a share of high-net-worth clients tends to be considerable. It means that further studies conducted in other national and market-specific contexts are more than appreciated.

\section{References}

ANDERLONI, L., Bongini, P. (2009). Is financial innovation still a relevant issue?, In: L. Anderloni, D.T. Llewellyn, R.H. Schmidt (Eds.), Financial Innovation in Retail and Corporate Banking. Edward Elgar, Cheltenham. Pp. 41-62. doi: |0.4337/978|848447|89.00008

AVLONITIS, G.J., Papastathopoulou, P.G., Gounaris, S.P. (200I). An empirically based typology of product innovativeness for new financial services: success and failure scenarios. Journal of Product Innovation Management, 18(5), 324-342. doi: 10.1 II I/I540-5885.1850324

AUDRETSCH, D. B., Feldman, M. P. (2004). Knowledge spillovers and the geography of innovation. Handbook of Regional and Urban Economics, 4, 27|3-2739. doi: 10.1016/ SI574-0080(04)800I8-X

BARRAS, R. (1986). Towards a theory of innovation in services. Research Policy, 15, 161-173. doi: 10.1016/0048$7333(86) 90012-0$

BARRAS, R. (1990). Interactive innovation in financial and business services: the vanguard of the service revolution. Research Policy, 19, 215-237. doi: 10.1016/00487333(90)90037-7

CARVALHO VEIRA, J.M., de Magalhaes Serra, E., Gonzalez, J.A.V. (2004). New services margin / high success discriminators. The Service Industries Journal, 24(5), 91-101. doi: 10.1080/0264206042000276856

CHESBROUGH, H.W. (2003). Open Innovation: The New Imperative for Creating and Profiting from Technology. Harvard Business School Press, Boston.

CHESBROUGH, H.W. (201I). Open Services Innovation: Rethinking Your Business to Grow and Compete in A New Era. San Francisco, CA

CHESBROUGH, H.W., Vanhaverbeke, W., West, J. (2006). Open Innovation: Researching a New Paradigm, Oxford University Press.
CIS (2008). Eurostat. Science and technology: results of the community innovation survey 2008. [online] http:// ec.europa.eu/eurostat/data/database (accessed 13 March 2015).

COASE, R. H. (1937). The nature of the firm. Economica 4(I6), 386-405. doi: I0.1 I I I/j. I468-0335. I 937.tb00002.x

COOPER R.G, de Brentani U.(199I). New industrial financial services: what distinguishes the winners. Journal of Product Innovation Management, 8(2), 75-90. Doi: 10.1III//5405885.820075

COOPER, R.G, Easingwood C.J, Edgett S., Kleinschmidt E.J., Storey C. (1994). What distinguishes the top performing new products in financial services. Journal of Product Innovation Management, I I (4), 28 I-299. doi: I0. I I I I/ 5405885. I|4028 |

COOPER, R.G., Edgett, S.J. (1996). Critical success factors for new financial services. Marketing Management, 5, 26-38.

COSTANZO, L.A., Ashton, J.K. (2006). Product innovation and consumer choice in the UK financial services industry. Journal of Financial Regulation and Compliance, 14(3), 285303. doi: $10.1108 / 1358$ | 980610685658

CSSF - Commission de Surveillance du Secteur Financier (20I2). List of banks established in Luxembourg in accordance with the Law of 5 April 1993. [online] Report, CSSF - Commission de Surveillance du Secteur, Financier

Luxembourg. http://www.cssf.lu/entites-surveillees/ (accessed 7 August 2012).

DAHLANDER, L., Gann, D.M. (2010). How open is innovation? Research Policy, 39(6), 699-709. doi: 10.1016/j. respol.2010.01.013.

DE BRENTANI, U., Cooper, R. (1992). Developing successful new financial services for businesses, Industrial Marketing Management,2I,23 I-24I.doi:I0. I0I6/00 I9-850 I(92)90020.t

DE YOUNG, R., Lang W.W., Nolle, D.L. (2007). How the internet affects output and performance at community banks. Journal of Banking and Finance, 31, 1033-1060. doi: 10.1016/j.jbankfin.2006.10.003

DEN HAAN, W. J., Sterk, V. (20I0). The myth of financial innovation and the great moderation. The Economic Journal, I2I, 707-739. doi: | 0. I I I /j. I468-0297.2010.02400.x

DREW, S.A.W. (1995). Accelerating innovation in financial services. Long Range Planning, 28(4), I- I0. doi: 10. I016/0024$630 I(95) 0003 \mathrm{I}-\mathrm{d}$ 
EDGETT, S. (1994). The traits of successful new service development. Journal of Services Marketing, 8(3), 40-49. doi: I0.1 108/08876049410065606

EDGETT, S., Jones, S. (199I). New product development in the financial service industry: a case study. Journal of Marketing Management, 7(3), 27I-284. doi: 10.1080/0267257X.1991.9964156

EDGETT, S., Parkinson, S. (1994). The development of new financial services: identifying determinants of success and failure. International Journal of Service Industry Management, 5(4), 24-38. doi: I0.1 108/09564239410068689.

FASNACHT, D. (2009). Open Innovation in the Financial Services, Springer-Verlag, Berlin. doi: 10.1007/978-3-540$88231-2$

FRAME,W. S.,White, L.J. (2004). Empirical studies of financial innovation: lots of talk, little action? Journal of Economic Literature, 42(I), I I6-I 44. doi: I0.2 I39/ssrn.325800

FURST, K., Lang, W.W., Nolle D. E. (2002). Internet banking: developments and prospects. Journal of Financial Services Research, 22, 95-II7. Doi: I0.2139/ssrn. 1988503

GASSMANN, O. and Enkel, E. (2004). Towards a theory of open innovation: three core process archetypes, in Proceedings of The R\&D Management Conference, Lisbon, Portugal.

GROSSMAN, G. M., Helpman, E. (1991). Trade, knowledge spillovers, and growth. European Economic Review, 35(2), 517-526. Doi: I0.1016/0014-292I(91)90153-a

HUIZINGH, E.K.R.E. (20I I). Open innovation: state of the art and future perspectives. Technovation, 3I(I), 2-9. doi: I0.1016/j.technovation.2010.10.002

JOHNE, F.A. and Davies, R. (2000). Innovation in mediumsized insurance companies: how marketing adds value. International Journal of Bank Marketing, I8(I), 6-14. doi: 10.1108/02652320010315316

LERNER, J. (2006). The new new financial thing: The origins of financial innovations. Journal of Financial Economics, 79(2), 223-255. Doi: I0.1016/j.jfineco.2005.0I.004

LERNER, J., Tufano P. (20II). The consequences of financial innovation: a counterfactual research agenda. Annual Review of Financial Economics, 3, 4I-85. doi: I0.3386/wl6780
LFF (20/2). Luxembourg for Finance. Etude d'impact de l'industrie financière sur l'économie luxembourgeoise: version chiffres de 2010. [online] Report, LFF - Luxembourg for Finance, Luxembourg. http://www.luxembourgforfinance. lu/etude-dimpact-de-lindustrie-financiere-sur-leconomieluxembourgeoise (accessed 5 February 2013).

LIEVENS, A., Moenaert, R. (2000). Project team communication in financial service innovation. Journal of Management Studies, 37(5), 733-766. doi: 10.1III/I4676486.00201

LIEVENS,A., de Ruyter, K., Lemmink,J. (I 999). Learning during new banking service development a communication network approach to marketing departments. Journal of Service Research, 2(2), I45-I63. doi: I0.I I77// 09467059922003

MARTOVOY A. (2014). Advantages and disadvantages of open innovation: evidence from financial services, in Mention A.-L. and Torkkeli M. (Eds.) Innovation in Financial Services: A Dual Ambiguity, Cambridge Scholars Publishing, Newcastle upon Tyne, 259-294.

MARTOVOY A. and Dos Santos J. (2012). Co-creation and co-profiting in financial services. International Journal of Entrepreneurship and Innovation Management, 16(I/2), II4135. doi: 10.1504/ijeim.2012.050446

MENOR, L.J., Roth, A.V. (2008). New service development competence and performance: an empirical investigation in retail banking. Production and Operations Management, I7(3), 267-284. doi: I0.340I/poms. I080.0034

MENTION, A.-L., Torkkeli M. (20I2). Drivers, processes and consequences of financial innovation: a research agenda. International Journal of Entrepreneurship and Innovation Management, I6(I/2), 5-29. doi: I0.I504/ijeim.20I2.05044I

MERTON, R.C. (1992). Financial innovation and economic performance. Journal of Applied Corporate Finance, 4, 12 -22. doi: |0.1 I I |/j. 1745-6622.1992.tb002 I4.x

OLIVEIRA, P., von Hippel, E. (20ll). Users as service innovators: the case of banking services. Research Policy, 40(6), 806-8I8. doi: I0.1016/j.respol.20II.03.009

PENNINGS, J.M., Harianto, F. (1992). The diffusion of technological innovation in the commercial banking industry. Strategic Management Journal, I3(I), 29-46. doi: 10.1002/ smj.4250I30I04 
ROSSIGNOLI, B., Arnaboldi, F. (2009). Financial innovation: theoretical issues and empirical evidence in Italy and in the UK. International Review of Economics, 56(3), 275-30I. Doi: I0.1007/s | 2232-009-0078-5

SCHEUING, E.E. and Johnson, E.M. (1989). New product development and management in financial institutions. International Journal of Bank Marketing, 7(2), I7-2I. doi: I0.1 I08/EUM000000000I454

SILBER, W.L. (1975). Financial innovation, Lexington, MA: Heath.

THOMKE, S. (2003). R\&D comes to services: Bank of Americas pathbreaking experiments, Harvard Business Review. 8I (4), 70-79.

THWAITES, D. (1992). Organizational influences on the new product development process in financial services, Journal of Product Innovation Management, 9, 303-313. doi: 10.1 II I/I540-5885.940303

THWAITES, D., Edgett, S. (1991). Aspects of innovation in a turbulent market environment: empirical evidence from UK building societies, The Service Industries Journal, I I(3), 34636I. doi: 10.1080/02642069100000050

UCHUPALANAN, K. (2000). Competition and IT-based innovation in banking services. International Journal of Innovation Management, 4(4), 455-489. doi: 10.1/42/ SI363919600000238

VERMEULEN, P. (2004). Managing product innovation in financial services firms. European Management Journal, 22(I), 43-50. doi: 10.1016/j.emj.2003.11.012

YILDIRIM, H.S., Philippatos, G.C. (2007). Restructuring consolidation and competition in Latin American banking markets. Journal of Banking and Finance, 31, 629-639. doi: I0.1016/j.jbankfin.2006.06.008

Z/YEN GROUP (20I5). The Global Financial Centres Index 17: March 20I5. [online] Report, Z/Yen Group, London, http://www.longfinance.net/images/GFClI7_23March20I5. pdf (accessed I0 April, 2015). 